\title{
Laparoscopic surgery into mixed hiatal hernia. Results pre-operative and post-operative
}

\author{
A. Pagán Pomar, E. Palma Zamora, A. Ochogavia Segui and M. Llabres Rosello ${ }^{1}$ \\ Service of General Surgery. Hospital Universitario Son Dureta. Palma de Mallorca, Spain. \\ ${ }^{\text {}}$ Service of Digestive Diseases. Hospital Comarcal de Inca. Palma de Mallorca, Spain
}

\begin{abstract}
Introduction: the complications of the mixed hernia need, often, surgical treatment. In the asymtomatic patients this one treatment is controversial, due to her complex repair and the high percentage of relapse informed in the long term. The surgical classic routes, they present raised morbi-mortality related to the extent of the incisions, to long hospitable stays and slow recovery.

Material and methods: between October, 2001 to November, 2007 we check 39 patients with hernia hiatal mixed with a middle ages of 65 years (35-78 years). In Lloyd-Davies's position, the content diminishes hernia and the redundant sack is resected. The diaphragmatic props are sutured by material not reabsorbable. Mesh of reinforcement intervened in 7/39 repairs. It concludes with a partial or complete antirreflux depending on the report.

Results: the operative average time was of $126 \mathrm{~min}$; the hospital stay of 2.46 days. The complications perioperatives are principally cardiorespiratory. A patient died for an intestinal inadvertent perforation during the intervention and of late diagnosis. We realize traffic gastroduodenal to 12 months in 28 patients (71.7\%). We find relapse in 8 patients (20.5\%). Four asymtomatic patients, with chance find in the radiological control. Three patients with pirosis that needs treatment and one of the relapses needed reintervention for strangulation of a gastric volvulus.

Conclusions: the laparoscopic surgery offers safety and efficiency with rapid postoperatory recovery, minor morbidity and hospitable stay. After the surgery, the long-term relapse presents similar results to the opened surgery, though the interposition of mesh can propitiate her decrease.
\end{abstract}

Key words: Hiatal hernia. Diaphragma hernia. Paraesophageal hernia. Laparoscopic antirreflux surgery. Prosthetic hiatal closure.

Received: 22-12-08.

Accepted: 15-01-09.

Correspondence: Alberto Pagán Pomar. Servicio de Cirugía General. Hospital Universitario Son Dureta. C/ Andrea Doria, 55. 07014 Palma Mallorca.e-mail: ajpagan@telefonica.net
A. Pagán Pomar, E. Palma Zamora, A. Ochogavia Segui and M. Llabres Rosello. Laparoscopic surgery into mixed hiatal hernia. Results pre-operative and post-operative. Rev Esp Enferm Dig 2009; 101: 623-630.

\section{INTRODUCTION}

The hiatal hernia can be classified into 3 groups; the sliding hiatal hernia or type I, the paraesophageal hiatal hernia or type II, and the mixed hernia or type III. This last type, depending on the content (bowel, oment, spleen...), could form a forth group in this classification (1).

Type I is by far the most frequent one, types II and III constituting less than $5 \%$ of all hiatal hernias. When there is a long evolution, the difference in pressure between the thoracic and the abdominal cavity, and the laxity of the phrenoesphageal membrane and the gastroesophageal attachment elements cause an increase in hernia volume. This may also be accompanied by a gastric slide and the eventual formation of a mesentericaxial gastric volvulus, the most frequent cause being a vascular pedicle fixation.

Traditionally, these hernias have been treated by toracotomy or laparotomy. However, the results of several series of operations have shown that not only is the laparoscopic approach more feasible and safe, but it also offers a wider therapeutic alternative with excellent short term results compared to open repairs $(2,3)$. It has been shown that there is a high incidence of recurrence in groups controlled by barium transit, in laparoscopic repair too $(4,5)$, whose surgical indication requires caution in asymptomatic hernia type III (6).

In this study, we offer our experience and the results obtained in the laparoscopic treatment of 39 mixed hernias, including post-operative radiological evaluations. 


\section{MATERIAL AND METHODS}

Between October 2001 and November 2007, we performed 175 laparoscopic fundoplications, 39 of which were mixed hernia corrections. Clinical information regarding complications or post-operative symptoms was obtained via personal interviews and quarterly following-ups.

We used a questionnaire, proposed by Shaw, on gastrointestinal symptoms (heartburn, retrosternal pain, dysphagia, pulmonary symptoms or bleeding) (7) and their severity -no symptoms (0), moderate but no medication (1), moderate with occasional medication (2), severe symptoms that need continuous treatment (3)-. Patients were clinically evaluated, before and after surgery, with the help of this questionnaire. Furthermore, by applying the Savary Miller classification, we practised an esophagoscopy in order to evaluate the degree of esophagitis. Whenever it was possible, pre-operative evaluation also included manometry and a 24-hour $\mathrm{pH}$ monitoring if symptoms or endoscopic findings were present.

Peristalsis was classified as normal when over $80 \%$ of peristaltic contractions of more than $30 \mathrm{mmHg}$ were in the lower third of the esophagus, or low amplitude when over $80 \%$ of peristaltic contractions of less than $30 \mathrm{mmHg}$ were in the same area. As part of the patients' follow-ups, a barium transit was performed a year after surgery.

\section{Surgical technique}

Patients were under general anesthesia and in the Lloyd-Davies position. Pneumoperitoneum was practiced $(12 \mathrm{mmHg})$ with a Veres needle. Five operative laparoscopic ports were used; three of them $5 \mathrm{~mm}$, for gastric traction, left hepatic lobe separation and the surgeon's left working hand. Hernia content reduction required a caudal maintained traction to avoid gastric reincorporation in the thoracic cavity until peritoneal adherences that fix the distal esophagus were completely liberated. We began the sack dissection liberating it from the left pillar (Fig. 1) and tractioning it to the right pillar, showing the esophagus body in the mediastinum until it was finally individualized with a ribbon that surrounded it to complete the retroesophagic dissection (Fig. 2). When the resulting peritoneal sack was redundant, we excised it to allow a good anchorage of the funduplication sutures.

For the dyaphragmatic closure, non-absorbable material was used. In the last 7 cases we used two types of mesh: PTFE dual mesh (WL Gore\&Assoc ${ }^{\circledR}$ ), and recently a colagen-poliester bilaminar mesh (Parietex composite ${ }^{\circledR}$, Sofradim, Covidien ${ }^{\circledR}$ ). In two of the cases, PTFE mesh was used, but at present we prefer Composite mesh because of its manageability and laxity that allows an easy anatomic adaptation, and comes presented in several precut models (Fig. 3). In all cases, we have completed the operation using an anti-reflux technique.

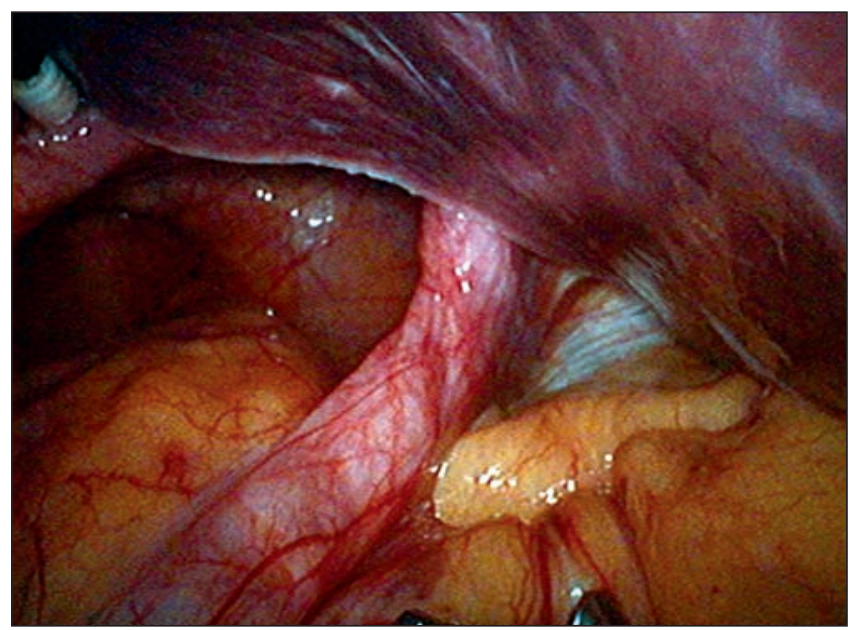

Fig, 1. Dissection liberating it from the left pillar

Exposición de pilar izquierdo previo al inicio de la disección.

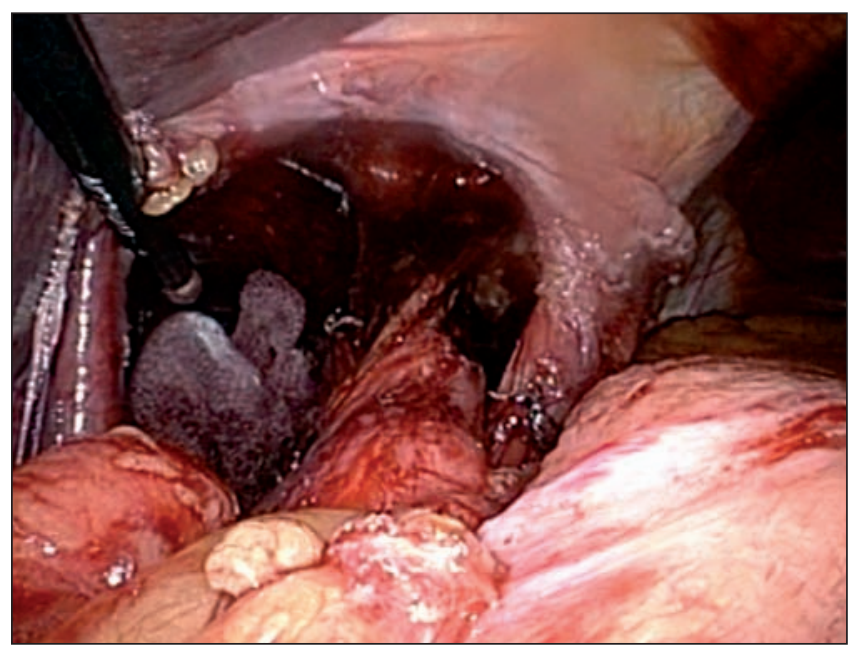

Fig. 2. Showing the esophagus body in the mediastinum.

Visualización de la disección esofágica y de ambos pilares tras la resección del saco herniario.

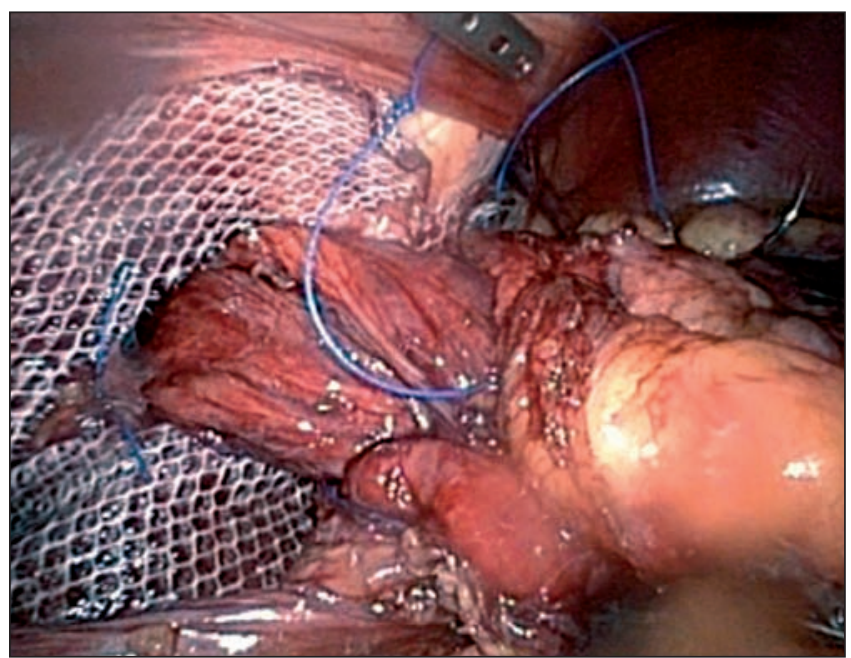

Fig. 3. Dyaphragmatic closure with non-absorbable material and colagen-poliester mesh (Parietex composite ${ }^{\circledR}$, Sofradim, Covidien ${ }^{\circledast}$ ).

Malla de poliéster ya colocada reforzando el cierre simple de los pilares. 


\section{RESULTS}

The 39 mixed hernias were divided into 37 type IIIs and 2 type IVs. Mixed hernias constituted $22.2 \%$ of all the hiatal hernias operated on in the given period. Regarding gender, 33 patients were women and 6 were men averaging 65 years old (35-78 years old). In the women's group, the average of 66 years old (47-75 years) was higher than in the men's group - 60 years old (35-78 years). Age range was between 35 and 78 years.

The most common pre-operative symptoms were retroesternal pain or epigastric oppression, dysphagia caused by solid food or anemia caused by chronic digestive bleeding. Heartburn was of little clinical relevance and was rare in this series (Table I).

Table I. Symptoms pre-operative and post-operative

\begin{tabular}{lcccc}
\hline & \multicolumn{2}{c}{$\begin{array}{c}\text { Pre-operative } \\
n=39\end{array}$} & $\begin{array}{c}\text { Post-operative } \\
n=34\end{array}$ \\
\hline & $n$ & $\begin{array}{c}\text { Score } \\
\text { severity }\end{array}$ & $n$ & $\begin{array}{c}\text { Score } \\
\text { severity }\end{array}$ \\
\hline Pyrosis & 4 & $0.72 \pm 0.1$ & 3 & $0.15 \pm 0.07$ \\
Dysphagia & 10 & $1.4 \pm 0.12$ & 4 & $0.23 \pm 0.07$ \\
Abdominal pain & 8 & $2.12 \pm 0.12$ & 1 & \\
HDA & 14 & $1.76 \pm 0.1$ & & \\
Other symptoms & 3 & $1.2 \pm 0.1$ & & \\
\hline
\end{tabular}

The mixed hernia diagnosis was confirmed in all cases with a barium study. A mesentericaxial gastric volvulus was found in two patients. Endoscopy was done on 29 patients, of whom 11 had some degree of esophagitis: grade I; grade I: 6 patients, grade II: 5 patients and grade III: 1 patient.

Esophagus manometry was done on 22 patients to determine esophageal body motility and to programme the correct fundoplicature technique. A normal peristalsis or non-specific motor disorder was found in 19 patients, and a low amplitude peristalsis in 3 of them. Finally, 24-hour pH-metry was carried out in 21 cases, which confirmed the presence of gastroesophagic reflux in 4 of them.

Average surgical time was $125 \mathrm{~min}(70-240 \mathrm{~min})$. The sack was removed in 19 patients, once the esophagus was completely liberated. Under calibration, dyaphragmatic pillar closure was done with no anterior closures in any of the cases. Mesh was needed in 7 patients because of pillar weakness. The anti-reflux technique used was the
Nissen-Rossetti in 36 patients and the Toupet in 3 cases. No gastropexia or other fixation procedures were performed.

One patient needed open surgery because of an aortic wall lesion during the pillar suture. There was an aortic elongation near the left pillar, which was not noticed during the dissection. The injury occurred at the beginning of the pillar suture due to a direct puncture.

Two re-interventions were performed. One patient in the immediate post-operatorative period, who was initially diagnosed with cardiogenic shock due to an arrhythmogenic history, finally died of a multi-organ failure caused by an inadvertent intestinal perforation. Another re-intervention, which was performed 8 months after the initial operation, was a complicated gastric volvulus that required gastrectomy and the removal of the previously placed mesh, probably too small to cover the hiatus area.

The average period of hospitalization after surgery was 2.2 days. Except from four patients, all of them tolerated liquids 12 hours after their operations.

Oppression and retroesternal pain improved in all of the patients. Dysphagia, which usually appeared in the first post-operative month, improved subsequently, except in 3 cases that presented weak symptoms relating to solid food intake. No dilatation was needed.

A global relapse of $20.5 \%$ was observed after an average follow-up of 22.6 months (5.7-65.4 months). Radiological monitoring were carried out between 6 and 12 months after surgery revealing 4 relapses with no symptoms, as well as three patients who had a relapse with pyrosis that responded to a proton pump inhibitor (Table II).

\section{DISCUSSION}

Laparoscopic correction of hiatal hernia is a safe and efficient alternative to traditional medical treatment $(2,8)$. Although hiatal hernias are classified in 3 groups, some authors add a forth group related to hernia content (9).

Literature quantifies the frequency of mixed hiatal hernia in $5 \%$ of cases $(10,11)$, but in our series it reached almost $23 \%$ of the cases. We believe, as other authors, that mixed hernias are the final stage of sliding hernias, and somehow indicate a delay in the diagnosis or the establishment of surgery.

Mixed hernias normally show gastric obstruction symptoms. As in other series, postprandial pain, retrosternal oppression and dysphagia are the most frequent, and can usually be ascribed to extrinsic compression of

Table II. Results of surgical treatment mixed hernia

\begin{tabular}{lcccccccc}
\hline Surgical & $n$ & Convery & Morbility & Mortality & Average hospital & Follow-up (months) & Relapses & $\begin{array}{c}\text { Evolution } \\
\text { well/very well }\end{array}$ \\
\hline Clousure pillar & 32 & 1 & $6(18 \%)$ & 0 & 2.57 & 28.27 & $6(18.75 \%)$ & $30(93.7 \%)$ \\
\hline Clousure pillar + MESH & 7 & 0 & $2(28.5 \%)$ & 1 & 2.71 & 17.90 & $1(14.2 \%)$ & $6(85.7 \%)$ \\
\hline
\end{tabular}


the stomach over the distal esophagus. The intermittent presentation of symptoms suggests a gastric rotation, due to the progressive laxity of anchoring structures, which in a long period will favour the appearance of complications. Although heartburn was not predominant, there were endoscopic findings of esophagitis in $30 \%$ of cases in our series. Depending on the realization of 24-hour pH-metry, this percentage varies between $19 \%$ by authors such as Myers and $67 \%$ by Gantert's series $(12,13)$.

We consider ambulatory 24-hour monitoring an unnecessary examination for these hernias as in most of the cases it is informed as normal, and we associate fundoplication as part of the surgical correction. Manometric study, whenever feasible, will show the esophagic body peristalsis and establish the indication of partial fundoplication if there is a low amplitude peristalsis, whereas complete fundoplication normally associates with more frequent post-operative dysphagia (14-17). A symptomatic mixed hernia diagnosis is an indication of elective surgery for most authors. It prevents an emergency procedure due to an incarceration or strangulation. Consequently, this leads a morbidity and mortality close to $20 \%$, determined by the age of the patients and their comorbidities (18-20).

Mixed hernia correction involved a greater, more complex risk of inter-operative complications. In our case, the aortic lesion related to an elongation. This complication has been previously described by Leggett (21).

Hernial sac resection, which used to arouse controversy $(22,23)$, is nowadays considered to be an indispensable technical gesture $(24,25)$. There is growing evidence pointing to reduced relapse in the mid term following placement of a mesh without increased complications (26-29). Granderath, among others, systematically recommends pillar closure using a mesh, considering that closure with simple sutures does not prevent the possibility of rupture and valve elevation. Although our use at the beginning of the series was limited due to the lack of consensus in literature, the technical complexity of its setting and the diversity of materials, we now believe that diafragmatic pillars showing tear or dilaceration during the simple suture should be strengthened with a mesh. There is no consensus on the appropriate type of mesh (27), so we have used two types, both double-sided designed for intraperitoneal placement, made with PTFE and polyester, being careful not to apply it to the esophagus. We currently use a polyester and hydolized collagen composite mesh because its features reduce the risk of a decubitus on neighbouring structures. Fixation was performed using nonresorbable suture, in some cases with helical sutures that were coated by applying a fibrin sealant (Tis$\left.\operatorname{sucol}^{\circledast}\right)$. The number of reported complications was low, but these may appear unusually late $(27,30,31)$. To date, we have not had any complications relating to the interposition of the mesh or its fixations.

Although the use of an antireflux technique in the treatment of these large hernias is controversial $(22,23)$, we always use it. We believe that it is justified on the ba- sis that up to $18 \%$ of patients present pyrosis after a simple repair (32), and surgical dissection of the gastroesophageal union alters physiological anti-reflux mechanisms.

The quality of life has improved in most patients. This group also includes those taking proton-pump inhibitors, who needed surgery to relieve thoracic or epigastric pain, respiratory symptoms or dysphagia due to esophageal compression in the mediastinum (33).

The rate of recurrence probably depends on the follow-up duration and its definition. It could either be described as a disruption of the hiatal closure with fundoplication rising to the chest, or as the presence of asymptomatic hernial poles discovered with a barium transit. Our series presents a recurrence rate of $20.5 \%$, although half of these cases were totally asymptomatic, thus over $85 \%$ of the patients reported outcome as good or very good in $(33,34)$.

In conclusion, the use of laparoscopic surgery in the treatment of mixed hernias in not only more feasible and safe than open surgery, but it also reduces post-operative morbidity and hospitalization. A wide dissection of the gastroesophageal union and distal esophagus is needed, with a hernial sac resection. Hiatal reconstruction by placing a double-sided mesh must also be considered when diafragmatic pillars are not high-quality; there seems to be a consensus in which placement of a mesh decreases the relapse without increasing complications. The association of an anti-reflux technique (Nissen, Nissen-Rossetti or Toupet), seems to complete the technique offering a better alternative to these patients to avoid or to reduce the appearance of pyrosis.

\section{REFERENCES}

1. Landrenau RJ, Del Pino M, Santos R. Management of paraesophageal hernias. Surg Clin N Am 2005; 85: 411-32.

2. Athanasakis H, Tzortzinis A, Tsiaoussis J, Vassilakis JS, Xynos E. Laparoscopic repair of paraesophageal hernia. Endoscopy 2001; 51: 590-4.

3. Huntington TR. Short-term outcome of laparoscopic paraesophageal hernia repair. A case series of 58 consecutive patients. Surg Endosc 1997; 11: 894-8.

4. Hashemi M, Peters JH, DeMeester TR, Huprich JE, Queck M, Hagen JA, et al. Laparoscopic repair of large type III hiatal hernia: objective follow-up reveals high recurrence rate. J Am Coll Surg 2000; 190: 553-601.

5. Targarona EM, Bendaham G, Balague C, Garriga J, Trias M. Mallas en el hiato: una controversia no solucionada. Cir Esp 2004; 75(3): 105-16.

6. Stylopoulos N, Gazelle GS, Rattner DW. Paraesophageal hernias: operation or observation? Ann Surg 2002; 236(4): 492-501.

7. Shaw MJ, Talley NJ, Beebe TJ, Rockwood T, Carlsoson R, Adlis S, et al. Initial validation of a diagnostic questionnaire for gastroesophageal reflux disease. Am J Gastroenterol 2001; 96: 52-7.

8. SAGES guidelines. Guidelines for surgical treatment of gastroesophageal reflux disease. Surg Endosc 1998; 12: 186-88.

9. Lal, DR, Pellegrini CA, Oelschlager BK. Laparoscopic repair of paraesophageal hernia. Surg Clin N Am 2005; 85: 105-18.

10. Skinner DB, Belsey RH. Surgical management of esophageal reflux and hiatus hernia. Long-term results with 1030 patients. J Thorac Cardiovasc Surg 1967; 53: 33-54. 
11. Sweet RH. Experience with 500 cases of hiatus hernia. J Thorac Surg 1962; 44: 145

12. Myers G, Harms B, Starling J. Management of paraesophageal hernias with a selective approach to antireflux surgery. Am J Surg 1995; 170: 375-80

13. Gantert WA, Patti MG, Arcerito M, Feo C, Stewart L, DePinto M, et al. Laparoscopic repair of paraesophageal hiatal hernias. J Am Coll Surg 1998; 186: 428-32.

14. Catarci M, Gentileschi P, Papi C, Carrara A, Marrese R, Gaspari AL, et al. Evidence-based appraisal of antireflux fundoplication. Ann Surg 2004; 239: 325-37.

15. Watson DI, Jamieson GG, Lally C, Archer S, Bessell JR, Booth M, et al. Multicenter, prospective, double-blind, randomized trial of laparoscopic Nissen vs anterior $90^{\circ}$ partial fundoplication. Arch Surg 2004; 139: 1160-7.

16. Pessaux P, Arnaud J-P, Ghavami B, Flament JB, Trebuchet G, Meyer $\mathrm{C}$, et al. Laparoscopic antireflux surgery: comparative study of Nissen, Nissen-Rossetti, and Toupet fundoplication. Surg Endosc 2000; 14: 1024-7.

17. Herbella FAM, Tedesco P, Nipomnick I, Fisichella PM, Patti MG. Effect of partial and total laparoscopic fundoplication on esophageal body motility. Surg Endosc 2007; 21: 285-8.

18. Carter R, Brewer LA 3rd, Hinshaw DB. Acute gastric volvulus. A study of 25 cases. Am J Surg 1980; 140: 99-106.

19. Haas O, Rat P, Christophe M, Friedman S, Favre JP. Surgical results of intrathoracic gastric volvulus complicating hiatal hernia. Br J Surg 1990; 77: 1379-81.

20. Geha AS, Massad MG, Snow NJ, Baue AE. A 32-year experience in 100 patients with giant paraesophageal hernia: the case for abdominal approach and selective antireflux repair. Surgery 2000; 128: 62330 .

21. Leggett PL, Bissell CD, Churchman-Winn R. Aortic injury during laparoscopic fundoplication: an underreported complication. Surg Endosc 2002; 16(2): 362 .

22. Kuster GG, Gilroy S. Laparoscopic technique for repair of paraesophageal hiatal hernias. J Laparoendosc Surg 1993; 3: 331-8.

23. Perdikis G, Hinder RA, Filipi CJ, Walenz T, McBride PJ, Smith SL, et al. Laparoscopic paraesophageal hernia repair. Arch Surg 1997;
132: 586-90.

24. Cuesta MA, vab der Poet DL, Klinkenberg-Knol EC. Laparoscopic treatment of large hiatal hernias. Semin Laparosc Surg 1999; 6: 213-23.

25. Vara Thorbeck C, Felices M, Toscazo R, Salvi M. Nuestra experiencia en el tratamiento de la hernia hiatal paraesofágica por vía laparoscópica. Cir Esp 2000; 68: 214-8.

26. Frantzides CT, Madan AK, Carlson MA, Stavropoulos GP. A prospective, randomized trial of laparoscopic polytetrafluoroethylene (PTFE) patch repair vs simple cruroplasty for large hiatal hernia. Arch Surg 2002; 137: 649-52.

27. Granderath FA, Carlson MA, Champion JK, Szold A, Basso N, Pointner R, et al. Prosthetic closure of the esophageal hiatus in large hiatal hernia repair and laparoscopic antireflux surgery. Surg Endosc 2006; 20: 367-79.

28. Objective follow-up after laparoscopic repair of large type III hiatal hernia. Assessment of safety and durability. World Surg 2007; 31: 2177-83.

29. Oelschlager BK, Pellegrini CA, Hunter J. Biologic prosthesis reduces recurrence after laparoscopic paraesophageal hernia repair. A multicenter, prospective, randomized trial. Ann Surg 2006; 244: 48190.

30. Arendt T, Stuber E, Monig H. Dysphagia due to transmural migration of surgical material into the esophagus nine years after Nissen fundoplication. Gastrointest Endosc 2000; 51: 607-10.

31. Kemppainen E, Kiviluoto T. Fatal cardiac tamponade after emergency tensión-free repair of a large paraesophageal hernia. Surg Endosc 2000; 14: 593.

32. Granderath FA, Kamolz T, Schweiger UM, Pointner R. Laparoscopic refundoplication with prosthetic hiatal closure for recurrent hiatal hernia after primary failed antireflux surgery. Arch Surg 2003; 138: 902-7.

33. Novell J, Targarona EM, Vela S, Cerdán G, Bendahan G, Torrubia S, et al. Resultados a medio plazo y calidad de vida del tratamiento laparoscópico de la hernia de hiato paraesofágica. Cir Esp 2004; 76(6): 382-7.

34. Parameswaran R, Ali A, Velmurugan S, Adjepong SE, Sigurdsson A. Laparoscopic repair of large paraesophageal hiatus hernia: quality of lile and durability. Surg Endosc 2006; 20(8): 1221-4.

\title{
Tratamiento quirúrgico laparoscópico en la hernia de hiato mixta. Resultados peroperatorios y del seguimiento a medio plazo
}

\author{
A. Pagán Pomar, E. Palma Zamora, A. Ochogavia Segui y M. Llabres Rosello ${ }^{1}$

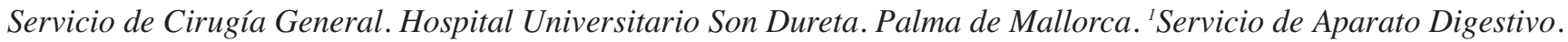 \\ Hospital Comarcal de Inca. Palma de Mallorca
}

\section{RESUMEN}

Introducción: las complicaciones de la hernia mixta requieren, con frecuencia, tratamiento quirúrgico. En los pacientes asintomáticos este tratamiento es controvertido, debido a su compleja reparación y al elevado porcentaje de recidivas informado a largo plazo. Las vías quirúrgicas clásicas presentan elevada morbimortalidad relacionada con la amplitud de las incisiones, con largas estancias hospitalarias y lenta recuperación.

Material y métodos: entre octubre de 2001 a noviembre de 2007 revisamos 39 pacientes con hernia hiatal mixta con una edad media de 65 años (35-78 años). En posición de Lloyd-Da- vies, se reduce el contenido herniario y se reseca el saco redundante. Se suturan los pilares diafragmáticos con material no reabsorbible. Se interpuso malla de refuerzo en 7/39 reparaciones. Se finaliza con un antirreflujo parcial o completo dependiendo del informe manométrico.

Resultados: el tiempo operatorio medio fue de $126 \mathrm{~min}$. La estancia hospitalaria de 2,46 días. Las complicaciones perioperatorias son principalmente cardiorrespiratorias. Un paciente falleció por una perforación intestinal inadvertida durante la intervención y de diagnóstico tardío. Realizamos tránsito gastroduodenal a los 12 meses en 28 pacientes (71,7\%). Encontramos recidiva en 8 pacientes $(20,5 \%)$. Cuatro pacientes asintomáticos, con hallaz- 
go casual en el control radiológico. Tres pacientes con pirosis que requiere tratamiento y una de las recidivas precisó reintervención por estrangulación de un vólvulo gástrico.

Conclusiones: la laparoscopia ofrece seguridad y eficacia con rápida recuperación postoperatoria, menor morbilidad y estancia hospitalaria. Tras la cirugía, la recidiva a largo plazo presenta similares resultados a la cirugía abierta, aunque la interposición de malla puede propiciar su disminución.

Palabras clave: Hernia hiatal. Hernia diafragmática. Hernia paraesofágica. Fundoplicatura laparoscópica. Reparación con malla.

\section{INTRODUCCIÓN}

Las hernias hiatales se clasifican en tres grandes grupos: hernias hiatales tipo I o por deslizamiento, las de tipo II o paraesofágicas y las hernias hiatales tipo III o mixtas, que dependiendo del contenido herniario (colon, omento mayor, bazo, etc.) formarían un cuarto grupo en la clasificación (1).

Dejando de lado la más frecuente, la hernia hiatal tipo I o por deslizamiento. Los tipos II y III ocurren en menos del 5\% de todas las hernias hiatales. Cuando su evolución es prolongada, la diferencia de presiones entre tórax y abdomen, la laxitud de la membrana frenoesofágica y de los elementos de fijación gastroesofágicos, originan un aumento de volumen herniario que puede acompañarse de deslizamiento gástrico y eventual formación de un vólvulo gástrico mesentérico-axial, con más frecuencia por la fijación del pedículo vascular.

Clásicamente estas hernias se han tratado por laparotomía o bien por toracotomía, pero los resultados de diversas series han permitido demostrar que la vía laparoscópica además de factible y segura ofrece una excelente opción terapéutica con unos resultados a corto plazo excelentes al compararlos con las reparaciones abiertas $(2,3)$. Se ha demostrado una elevada incidencia de recidiva en aquellos grupos controlados mediante TEGD, también en la reparación laparoscópica $(4,5)$, que obliga a ser cautos en la indicación quirúrgica ante hernias de tipo III asintomáticas (6).

En este estudio aportamos nuestra experiencia de 39 casos en el tratamiento de hernias mixtas por vía laparoscópica y una evaluación radiológica postoperatoria tardía con los resultados obtenidos.

\section{MATERIAL Y MÉTODOS}

Durante el periodo comprendido entre octubre de 2001 a noviembre de 2007 hemos realizado 175 fundoplicaturas laparoscópicas del esófago distal, de las cuales 39 eran correcciones por hernias mixtas o hernias tipo IV a los que se practicó una fundoplicatura laparoscópica. La información clínica fue obtenida mediante la entrevis- ta personal preoperatoriamente y las complicaciones o los síntomas posteriores a la cirugía mediante un seguimiento trimestral. Se utilizó el cuestionario propuesto por Shaw sobre síntomas gastrointestinales (7): pirosis, dolor retroesternal, disfagia, síntomas pulmonares o sangrado; y sobre su severidad: (0) sin síntomas, (1) moderados sin medicación, (2) moderados con medicación esporádica o (3) síntomas severos con necesidad de medicación continua. La clínica de los pacientes se evaluó preoperatoriamente y postoperatoriamente con este cuestionario. Practicamos también una esofagoscopia para valorar el grado de esofagitis usando la clasificación de Savary Miller. La valoración preoperatoria también incluyó manometría y monitorización de $\mathrm{pH}$ de 24 horas ante la presencia de síntomas o hallazgos endoscópicos, en aquellos pacientes en los que fue posible su realización. El peristaltismo fue clasificado como normal $(\geq 80 \%$ de contracciones peristálticas de más de $30 \mathrm{mmHg}$ en el tercio inferior del esófago) o de baja amplitud ( $\geq 80 \%$ de contracciones peristálticas de menos de $30 \mathrm{mmHg}$ ). Durante el seguimiento se realiza un tránsito baritado a los 12 meses de la intervención.

\section{Técnica operatoria}

Se hace bajo anestesia general y con el paciente en posición de Lloyd-Davies. Se practica neumoperitoneo hasta $12 \mathrm{mmHg}$ con aguja de Verres. Utilizamos 5 trocares operatorios, tres de ellos $5 \mathrm{~mm}$ : para la tracción gástrica, separación del lóbulo hepático izquierdo y mano izquierda de trabajo del cirujano. La reducción del contenido de la hernia requiere tracción caudal mantenida para evitar la reincorporación gástrica hacia la cavidad torácica hasta la liberación completa de las adherencias laxas y peritoneales que fijan el esófago en su tercio distal. Iniciamos la disección del saco liberándolo del pilar izquierdo (Fig. 1) y traccionándolo hasta el pilar derecho, exponiéndose el cuerpo del esófago en el mediastino hasta que finalmente es individualizado mediante una cinta que lo rodea para completar la disección retroesofágica (Fig. 2). Cuando el saco peritoneal resultante es muy redundante, se extirpa para permitir un buen anclaje de los puntos de la fundoplicatura.

Para el cierre diafragmático se utilizan puntos de material no reabsorbible. Hemos utilizado en los últimos 7 casos dos tipos de malla. Se usaron dos tipos de malla: una de PTFE Dual Mesh WL Gore\&Assoc ${ }^{\circledast}$ y más recientemente una bilaminar de poliéster-colágeno Parietex composite $^{\circledast}$, Sofradim, Covidien ${ }^{\circledast}$. En 2 casos se utilizó una malla de PTFE aunque actualmente preferimos la Composite Mesh por su manejabilidad y laxitud que permite una adaptación fácil a la estructura anatómica y se presenta precortada en varios modelos (Fig. 3). En todos los casos hemos completado la operación con una técnica antirreflujo. 


\section{RESULTADOS}

Las 39 hernias mixtas, se subdividían en 37 hernias de tipo III y 2 hernias de tipo IV. Corresponden al $22,2 \%$ de todas las hernias de hiato intervenidas por un solo cirujano en ese periodo. La distribución por sexo: 33 mujeres y 6 hombres. La edad media fue de 65 años (35-78 años), superior en el grupo de las mujeres, 66 años (47-75 años) frente al de los varones 60 años (35-78 años). El rango de edad está entre 35 y 78 años.

Los síntomas preoperatorios se relacionaron más comúnmente con dolor u opresión retroesternal o epigástrica, disfagia causada por alimentos consistentes o anemia por hemorragia digestiva crónica. La pirosis es de escasa relevancia clínica y poco frecuente en la serie (Tabla I). El diagnóstico de hernia mixta se confirmó en todos los casos con el estudio baritado. En dos pacientes se informó la presencia de un vólvulo gástrico mesentéricoaxial. La endoscopia se realizó en 29 pacientes de los cuales 11 tenían algún grado de esofagitis: grado I: 6 pacientes, grado II: 5 pacientes y grado III: 1 paciente.

Tabla I. Síntomas preoperatorios y postoperatorios

\begin{tabular}{lcccc}
\hline & \multicolumn{2}{c}{$\begin{array}{c}\text { Preoperatorio } \\
n=39\end{array}$} & \multicolumn{2}{c}{$\begin{array}{c}\text { Postoperatorio } \\
n=34\end{array}$} \\
\hline & $n$ & $\begin{array}{c}\text { Score } \\
\text { severidad }\end{array}$ & $n$ & $\begin{array}{c}\text { Score } \\
\text { severidad }\end{array}$ \\
\hline Pirosis & 4 & $0,72 \pm 0,1$ & 3 & $0,15 \pm 0,07$ \\
Disfagia & 10 & $1,4 \pm 0,12$ & 4 & $0,23 \pm 0,07$ \\
Dolor abdominal & 8 & $2,12 \pm 0,12$ & 1 & \\
HDA & 14 & $1,76 \pm 0,1$ & & \\
Otros & 3 & $1,2 \pm 0,1$ & & \\
\hline
\end{tabular}

La manometría esofágica pudo realizarse en 22/39 de los casos para determinar la motilidad en el cuerpo esofágico y programar el tipo de fundoplicatura. Se encontró un peristaltismo normal o desorden motor inespecífico en 19 pacientes y peristaltismo de baja amplitud en 3 pacientes. Por último, la pHmetría de 24 horas se realizó en 21/39 casos, confirmándose la presencia de reflujo gastroesofágico en 4 casos.

El tiempo operatorio medio fue de $125 \min (70-240$ min). En 19/39 se resecó el saco una vez fue liberado completamente el esófago. Bajo calibración se realizó el cierre posterior de los pilares diafragmáticos, en ninguno se realizó cierre anterior del hiato esofágico. En 7/39 pacientes fue necesaria la aplicación de malla por debilidad de los pilares. La técnica antirreflujo empleada fue la de Nissen-Rossetti en 36 pacientes y Toupet en 3 casos. No se realizó gastropexia ni otros procedimientos de fijación.

Fue reconvertido un paciente por lesión de la pared aórtica durante la sutura de los pilares. Dicha elongación aórtica la alojaba en la proximidad del pilar izquierdo y dicha disposición anatómica no fue advertida durante la disección. La lesión ocurrió al iniciar la sutura de los pilares por su punción directa.

Se realizaron dos reintervenciones. Una en el postoperatorio inmediato en un paciente al que inicialmente se diagnosticó de choque cardiogénico por proceso arritmógeno debido a sus antecedentes patológicos y al que finalmente se objetivó una perforación intestinal inadvertida falleciendo por un fracaso multiorgánico. Otra reintervención fue realizada a los 8 meses de la fundoplicatura por presentar un vólvulo gástrico complicado tras la disrupción que obligó a gastrectomía y a la retirada de la malla interpuesta de tamaño reducido y probablemente no suficiente para cubrir el área hiatal.

La estancia media depurada en el hospital fue de 2,2 días tras la intervención. Salvo 4 pacientes, todos toleraron líquidos a partir de las $12 \mathrm{~h}$ de la intervención.

Se registró mejoría de los síntomas de opresión y dolor retroesternal en todos los pacientes. La disfagia que se reportó corresponde al primer mes postquirúrgico, con mejoría posterior salvo en tres casos que presentan leves síntomas relacionados con la ingesta de alimentos muy consistentes. No fue precisa ninguna dilatación.

Se ha objetivado una recidiva global del $20,5 \%$, tras un seguimiento medio de 22,6 meses de seguimiento (5,765,4 meses). Los controles radiológicos realizados entre 6-12 meses de la intervención evidenciaron cuatro recidivas únicamente radiológicas en forma de polo herniario que no presentan síntomas y tres pacientes presentan recidiva clínica con pirosis que responde a los inhibidores de bomba de protones (Tabla II).

\section{DISCUSIÓN}

La corrección laparoscópica de la hernia hiatal es una alternativa segura y efectiva al tratamiento médico $(2,8)$. Aunque las hernias hiatales se clasifican en tres grandes grupos, algunos autores exponen un cuarto grupo relacionado con el contenido herniario (9).

Tabla II. Resultados del tratamiento quirúrgico de las hernia mixtas

\begin{tabular}{|c|c|c|c|c|c|c|c|c|}
\hline Técnica & $n$ & Conversión & Morbilidad & Mortalidad & Estancia & Seguimiento (meses) & Recidiva & $\begin{array}{c}\text { Evolución } \\
\text { buena/muy buena }\end{array}$ \\
\hline Cierre pilares y FL & 32 & 1 & $6(18 \%)$ & 0 & 2,57 & 28,27 & $6(18,75 \%)$ & $30(93,7 \%)$ \\
\hline Cierre pilares con malla y FL & 7 & 0 & $2(28,5 \%)$ & 1 & 2,71 & 17,90 & $1(14,2 \%)$ & $6(85,7 \%)$ \\
\hline
\end{tabular}


La literatura cifra la frecuencia de la hernia hiatal mixta en el 5\% de los casos $(10,11)$, sin embargo en nuestra serie esta proporción alcanza casi el $23 \%$ de los casos, Creemos, como otros autores, que las hernias mixtas son el estadio final de una hernia por deslizamiento e indican de algún modo el retraso para realizar un diagnóstico o establecer una actitud terapéutica quirúrgica.

La clínica en la hernia mixta habitualmente manifiesta síntomas de obstrucción gástrica. Al igual que en otras series, el dolor postprandial, la opresión retroesternal y la disfagia son los más frecuentes, y usualmente se atribuyen a la comprensión extrínseca del estómago sobre el esófago distal. La presentación intermitente de estos síntomas sugiere una rotación gástrica propiciada por la progresiva laxitud de las estructuras de anclaje que a la larga favorecerá la aparición de complicaciones. Sin ser predominante, existe clínica de pirosis y hallazgos endoscópicos de esofagitis en el $30 \%$ de casos de nuestra serie. Este porcentaje varía en función de la realización de estudios de pHmetría, desde el 19\% de autores como Myers hasta el $67 \%$ en la serie de Gantert $(12,13)$.

Consideramos la monitorización ambulatoria de $\mathrm{pH}$ de 24 horas un examen innecesario en estas hernias, ya que en la mayoría de los casos es normal y asociamos una fundoplicatura como parte de la corrección quirúrgica. El estudio manométrico, cuando es posible realizarlo, permitirá conocer el peristaltismo del cuerpo esofágico y establecer la indicación de una fundoplicatura parcial ante un peristaltismo de baja amplitud frente a una fundoplicatura completa que habitualmente se asocia con mayor frecuencia a disfagia postoperatoria (14-17).

El diagnóstico de hernia mixta sintomática tiene indicación de cirugía electiva para la mayoría de autores. Se previene un procedimiento de urgencia, debido a complicación por incarceración o estrangulación, que presenta una morbimortalidad, condicionada por la edad avanzada de los pacientes y las comorbilidades asociadas, y que está cercana al 20\% (18-20).

La corrección del la hernia mixta conlleva mayor complejidad y riesgo de complicaciones intraoperatorias; en nuestro caso, una lesión aórtica relacionada con una elongación. Esta complicación ya fue descrita por Leggett (21).

Lo que inicialmente fue una controversia $(22,23)$, la resección del saco herniario, actualmente es un gesto técnico considerado indispensable $(24,25)$. Existen más evidencias que apuntan a la disminución de la recidiva a medio plazo tras la colocación de una malla, sin aumentar las complicaciones relacionadas con esta colocación (26-29). Granderath, entre otros, asocia de forma sistemática al cierre de los pilares la colocación de una malla, al considerar que el cierre simple con suturas no evita la posibilidad de ruptura de las mismas y el ascenso de la válvula. Aunque nuestro uso al inicio de la serie ha sido limitado, debido a la falta de consenso en la literatura durante el desarrollo de la serie, a la complejidad técnica que representa su colocación y a la diversidad de materiales, pensamos actualmente que deben reforzarse los pilares del diafragma que muestren desgarro o dislaceración durante la realización de la sutura simple mediante la interposición de una malla. Al no existir consenso sobre el tipo de malla (27), hemos usado dos tipos de malla, ambas de doble cara diseñadas para su colocación intraperitoneal, compuestas con PTFE y poliéster, con la precaución de no aplicarlas sobre el esófago. Actualmente utilizamos la Composite Mesh de poliéster y colágeno hidrolizado debido a sus características que evitarán el decúbito sobre las estructuras de vecindad. La fijación se realizó mediante suturas irreabsorbibles y en algunos casos con suturas helicoidales, que fueron recubiertas mediante la aplicación de un sellante de fibrina $\left(\right.$ Tissucol $\left.^{\circledR}\right)$. El número de complicaciones informado es bajo, aunque excepcionalmente pueden aparecer tardíamente $(27,30,31)$. No hemos tenido complicaciones relacionadas con la interposición de las mallas ni con sus fijaciones, hasta ahora.

La asociación de una técnica antirreflujo en el tratamiento de estas grandes hernias es controvertida $(22,23)$. Nosotros la venimos realizando independientemente de la presencia o no de clínica de reflujo. Creemos que se justifica en base a que hasta el $18 \%$ de pacientes presentan pirosis en el postoperatorio tras una simple reparación anatómica (32) y que la disección quirúrgica de la unión gastroesofágica altera los mecanismos fisiológicos de antirreflujo.

Existe una mejoría en la calidad de vida percibida en la mayoría de los pacientes. Incluso aquellos pacientes sintomáticos con toma de inhibidores de bomba de protones presentan mejoría de los síntomas, como el dolor torácico o epigástrico, la repercusión respiratoria o la disfagia fruto de la compresión esofágica en el mediastino, a los que fue indicada la intervención (33).

El porcentaje de recidiva depende probablemente del tiempo de seguimiento y de su definición. Esta engloba desde la disrupción del cierre hiatal con ascenso de la fundoplicatura al tórax hasta la presencia de polos herniarios asintomáticos descubiertos con la realización del tránsito baritado. Nuestra serie presenta una recidiva del $20,5 \%$, aunque la mitad se hallan totalmente asintomáticos y valoran su evolución como buena o muy buena en más del $85 \%$ de los casos $(33,34)$.

Concluimos que el tratamiento quirúrgico en la hernia mixta es posible y seguro. La aproximación laparoscópica a esta enfermedad supone una opción frente a las vías de abordaje abiertas al acortar la morbilidad postquirúrgica y la estancia postoperatoria. Es necesaria una amplia disección de la unión gastroesofágica y del tercio inferior del esófago junto con la resección del saco herniario. La reconstrucción del hiatus con la interposición de una malla de doble capa debe ser considerada cuando los pilares diafragmáticos no sean de calidad dado el consenso que parece existir en que su colocación disminuye la recidiva sin aumento de las complicaciones. La asociación de una técnica antirreflujo (Nissen, Nissen-Rossetti o Toupet), parece complementar la técnica ofreciendo una mejor alternativa a estos pacientes al evitar o reducir la aparición de pirosis. 